
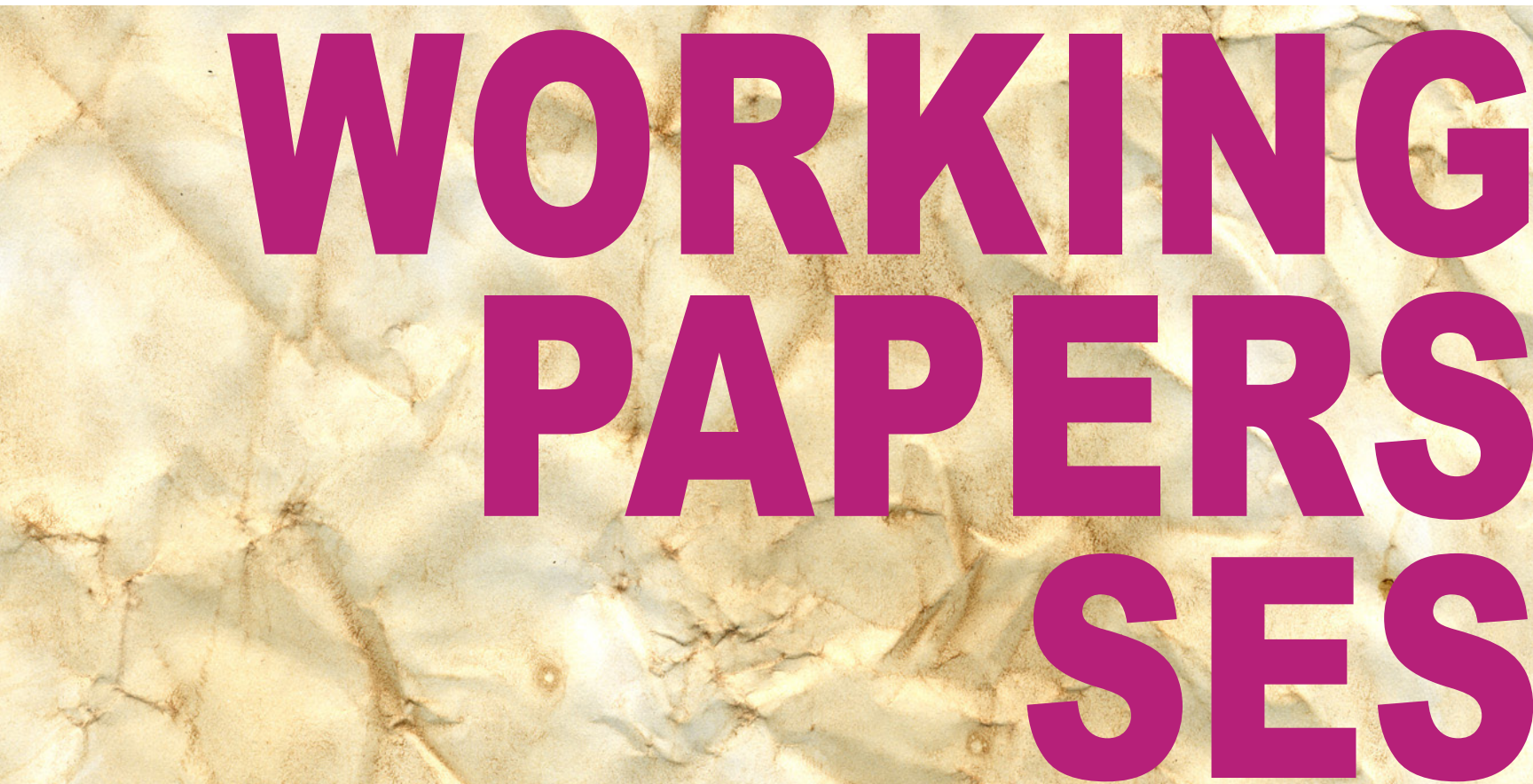

\title{
Chasing dividends during the COVID-19 pandemic
}

Nicolas Eugster, Romain Ducret, Dušan Isakov, and Jean-Philippe Weisskopf 


\title{
Chasing dividends during the COVID-19 pandemic
}

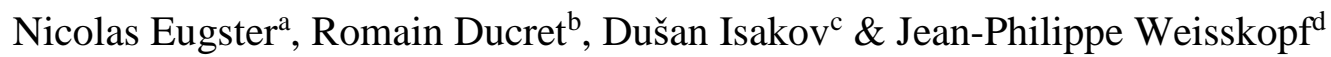

This version: September 24, 2020

\begin{abstract}
This paper investigates the impact of the COVID-19 pandemic on the trading behavior of investors around ex-dividend dates in Europe. The sudden decrease in the number of companies paying dividends reduced the opportunities to capture dividends. The firms that have maintained dividend payments during the pandemic thus attracted more interest than before. This led to a doubling in the magnitude of stock return patterns usually observed around exdividend days. Our evidence indicates that dividend-seeking investors are likely to be the main driver of the price patterns observed around ex-dividend dates.
\end{abstract}

JEL: G12; G14; G35

Keywords: COVID-19; dividend capture; price pressure; ex-dividend date; event study

${ }^{a}$ Corresponding author: University of Queensland, University of Queensland Business School, St Lucia, Brisbane 4072, Australia. Email: n.eugster@uq.edu.au

${ }^{\mathrm{b}}$ University of Fribourg, Faculty of Management, Economics and Social Sciences, Boulevard de Pérolles 90, 1700 Fribourg, Switzerland. Email: romain.ducret@unifr.ch

${ }^{\mathrm{c}}$ University of Fribourg, Faculty of Management, Economics and Social Sciences, Boulevard de Pérolles 90, 1700 Fribourg, Switzerland. Email: dusan.isakov@unifr.ch

${ }^{\mathrm{d}}$ Ecole hôtelière de Lausanne, HES-SO Haute école spécialisée de Suisse Occidentale, Route de Cojonnex 18, 1000 Lausanne, Switzerland. Email: jean-philippe.weisskopf@ehl.ch 


\section{Chasing dividends during the COVID-19 pandemic}

\section{Introduction}

The COVID-19 pandemic has deeply impacted businesses worldwide. Due to the large drop in consumption following widespread lockdowns, many companies have seen their revenues and profits decline, and their financial position deteriorate. In order to mitigate financial concerns or to ensure corporate survival, a number of firms have further decided to forego dividend payments and to keep the cash. Others, such as financial institutions, were prohibited or strongly discouraged by regulators to pay dividends leading to heated debates in the media and amongst politicians in many countries. As a result, one-third of firms in our universe decided to suspend dividend payments. This also had negative consequences on investors looking for dividend-paying stocks. In this paper, we thus examine how the pandemic affected stock price patterns of Western European companies surrounding the ex-dividend day, as COVID-19 (and the associated lockdowns) surprisingly hit this region just before the dividend distribution season.

Studies on stock price behavior around ex-dividend days have a long-standing history (Campbell and Beranek, 1955). In perfect capital markets, the stock price drop should equal the amount of the dividend paid out on the ex-dividend day. Many studies over the past fifty years have shown that this is not the case. The ex-dividend day premium (the ratio of price decline to dividend) has been shown to be consistently below one, thus generating positive returns (e.g., Elton and Gruber, 1970 or Eades et al., 1994). Over time, several reasons have been offered to explain this phenomenon. ${ }^{1}$

\footnotetext{
${ }^{1}$ For additional references and a broader overview of the topic please refer to surveys by Allen and Michaely
} (2003) or Farre-Mensa et al. (2014). 
Elton and Gruber (1970) propose a tax clientele effect. The stock price and ex-dividend day behavior will depend on the difference in taxation between capital gains and dividends. Later studies (e.g., Frank and Jagannathan, 1998) contradict this finding as the effect appears to remain in the absence of differential tax treatments. Kalay (1982) proposes that the insufficient price drop reflects the transaction costs of arbitrageurs trading such stock. These short-term traders will generate abnormal profit through dividend capturing. Michaely and Vila (1995), in a dynamic dividend clientele model, reconcile both explanations by examining all types of traders affecting the equilibrium price on the ex-dividend day. Finally, market microstructure may also explain the existence of this phenomenon. Bali and Hite (1998) and Frank and Jagannathan (1998) show that both price discreteness and a bid-ask bounce affect the exdividend price drop.

More recently, studies have incorporated behavioral aspects to explain stock price patterns around recurring corporate events ${ }^{2}$, such as dividend payments. Supply and demand for dividend-paying stocks are likely to shift a few days before the ex-dividend day as some investors buy the stock to capture the dividend. This will attract arbitrageurs who will profit from offsetting price movements due to this dividend-motivated trading. If a demand overhang exists, and arbitrageurs cannot counterbalance it, stock prices should increase (Eades et al., 1985, Hartzmark and Solomon, 2013). If price pressure is responsible for positive abnormal returns before dividend payments, one ought to observe a decrease in prices after the exdividend day (Lakonishok and Vermaelen, 1986, Hartzmark and Solomon, 2013). This pattern in prices is termed the dividend month premium. Its existence has been corroborated internationally (Ainsworth and Nicholson, 2014, Koo and Chae, 2020, Kreidl and Scholz, 2020) and for several types of dividends (Bessembinder and Zhang, 2015, Berkman and Koch, 2017). Different explanations for this phenomenon have been proposed in the literature. They include

\footnotetext{
${ }^{2}$ For literature on recurring corporate events and the linkage to stock returns see Hartzmark and Solomon (2018).
} 
catering theory (Baker and Wurgler, 2004), mutual funds' investments in dividend-paying stocks before the ex-dividend date to increase their dividend yield (Harris et al., 2015), or investors' lack of attention in the stock price reduction from the cum-dividend to ex-dividend dates (Hartzmark and Solomon, 2019).

In the context of the COVID-19 pandemic, we argue that the dividend month premium may be altered due to the exceptional situation faced by investors. We do not take position on the drivers of the ex-dividend day premium. We hypothesize that a taxation and/or microstructure effect may exist, but both aspects should be reasonably unaffected by the emergence of COVID-19. We, however, expect the previously reported price pressure to be more intense. Indeed, the substantial decline in the number of dividend-paying companies should push dividend-seeking investors towards the remaining opportunities, sharply increasing demand for these stocks. Arbitrageurs may not be able to offset this sudden demand enough, leading to higher-than-normal abnormal returns.

Our empirical results show that the price patterns observed around ex-dividend dates during the COVID-19 pandemic are amplified and indicate that dividend-seeking investors are likely to be the main cause of these price changes. Concretely, an investor buying a stock five days before the ex-dividend date and selling it at the opening of the ex-day, would have earned an average abnormal return of $2.14 \%$ during the COVID period. This is close to double the average premium obtained on an equivalent trade in the pre-COVID period. Our paper contributes to the literature examining the stock price behavior around recurring corporate events by studying how an exogenous shock impacts the decision-making of investors. More specifically, we confirm the price pressure explanation of Hartzmark and Solomon (2013) and highlight the important role of dividend-chasing investors in the predictable evolution of stock prices around ex-dividend dates. 


\section{Data and methodology}

\subsection{Sample}

The dataset covers the universe of publicly-listed Western European companies. To assure that companies show a minimum standard, the sample is limited to companies traded in their own country (i.e., avoiding international cross-listings) and on a country's major exchange (i.e., avoiding domestic cross-listings). Companies must also have been active in July 2020. We further restrict the sample to investable companies by implementing the following two restrictions: the stock price is above EUR 1.00 and the market capitalization higher than EUR 50 million. The final sample includes 2,248 companies from 16 Western European markets $^{3}$. All data is downloaded for the period January 2018 to July 2020 from Refinitiv Datastream and converted into EUR for markets outside the Eurozone.

\subsection{Methodology}

To evaluate whether the COVID-19 pandemic has impacted trading around ex-dividend dates, we divide our sample into two groups: dividend payments occurring before (pre-COVID) and after (COVID) the pandemic started. As a cut-off date, we use February $24^{\text {th }}, 2020$, which is the first day of lockdown in a Western European country. The COVID period thus encompasses the period 24/02/2020 to 31/07/2020. The pre-COVID period is used as a control group and covers the period 01/01/2018 to 23/02/2020.

For our analysis, we use an event study methodology in line with prior literature (Brown and Warner, 1985, Campbell et al., 1997). The daily returns of stocks are calculated in the following way

$$
R_{i, t}=\frac{P_{i, t}+D_{i, t}-P_{i, t-1}}{P_{i, t-1}}
$$

\footnotetext{
${ }^{3}$ A list of the 16 markets considered in this study can be found in Table 2.
} 
where $P_{i, t}$ is the closing price on day $t$ for stock $i$ (except for $t 0$ where it is the opening price on the ex-date) and $D_{i, t}$ the dividend per share which was paid out. $R_{i, 0}$ thus corresponds to an overnight return of a stock going from cum to ex (after the stock exchange closes), while $R_{i,+1}$ is measured from the opening of the ex-date to the closing of the subsequent day.

Abnormal returns are calculated by deducting market returns from stock returns as

$$
A R_{i, t}=R_{i, t}-R_{m, t}
$$

where daily market returns $\left(R_{m, t}\right)$ are calculated for each of the corresponding 16 benchmark indices ${ }^{4}$. We then winsorize all $A R_{i, t}$ at the $0.1-99.9 \%$ level and calculate average abnormal returns $\left(A A R_{t}\right)$ as

$$
A A R_{t}=\frac{1}{N} \sum_{i=1}^{N} A R_{i, t}
$$

with $A R_{i, t}$ for a given period (e.g., pre-COVID and COVID), and cumulated average abnormal returns for a given event window as

$$
C A A R=\sum_{t=1}^{T} A A R_{t}
$$

Berkman and Koch (2017) document that stocks with higher dividends have higher abnormal returns on the ex-day. In supporting tests, we thus divide the sample into firms with high (yearly upper quartile dividend yield) versus low dividend yields (bottom three quartiles) and estimate AARs and CAARs according to equations [3] and [4] for both subsamples. Finally, we examine the drivers of stock performance in the cross-section with the following specification

$$
\begin{aligned}
y_{i j t}=\alpha_{i}+ & \delta_{1 i} \text { High_preCOVID }+\delta_{2 i} \text { High_COVID }+\delta_{3 i} L_{-} \text {How }_{-} \text {COVID } \\
& +\beta_{i} X_{j t}+\theta_{i} \text { Industry }+\omega_{i} \text { Country }+\varepsilon_{i j t}
\end{aligned}
$$

\footnotetext{
${ }^{4}$ We use the following indices: ATX, BEL All-share, OMX Copenhagen, OMX Helsinki, CAC All-tradable, XETRA Prime All-share, Athex Composite, ISEQ All-share, FTSE MIB, AEX, Oslo SE OBX, PSI All-share, Madrid SE IGBM, OMX Stockholm, Swiss Performance Index, FTSE All-share.
} 
where $y_{i, j, t}$ measures the CAR for different time windows $i$ for company $j$ in year $t$. High_preCOVID $D_{t}$ denotes a dummy equal to one for companies paying a dividend that is higher than the yearly upper quartile dividend yield in the pre-COVID period. High_COVID $h_{t}$ is a dummy indicating a high dividend yield firm in the COVID period. Low_COVID $t$ is a dummy indicating companies paying a dividend that is lower than the yearly upper quartile dividend yield in the COVID period. $X_{j, t}$ is a vector of firm-level characteristics. Following Zhang et al. (2008), we include the relative risk (defined as the variance of a stock over its respective market variance over 40 days), beta (defined as the regression coefficient of a stock's returns on the returns of its respective market index over a 250-day window), and size (defined as the natural logarithm of a company's market capitalization). All three variables are calculated 21 days before the ex-dividend day. We also include country and industry dummies and cluster standard errors at the firm level.

\subsection{Descriptive statistics}

Table 1 provides evidence on the temporal evolution of dividend payouts for all companies (payers and non-payers) of the sample and an identical time period (24/02 to 31/07 of the respective year).

Table 1

Effect of COVID-19 on dividend payments

\begin{tabular}{cccccc}
\hline Year & Payers & Stop dividend & Total & $>25 \%$ & Firms \\
& & & $7.45 \%$ & $4.58 \%$ & 2,750 \\
2018 & $66.69 \%$ & $7.64 \%$ & $9.74 \%$ & $5.49 \%$ & 2,843 \\
2019 & $66.41 \%$ & $6.16 \%$ & $10.60 \%$ & $7.66 \%$ & 2,886 \\
2020 & $35.76 \%$ & $33.58 \%$ & & \\
\hline
\end{tabular}

This table reports, for the period 24/02 to 31/07 of each year, the fraction of dividend payers, companies stopping dividend payments, and firms reducing payments (overall or by more than $25 \%$ ).

The fraction of payers in our sample dropped from $66.41 \%$ to $35.76 \%$ over the last year. Moreover, about one-third of companies paying a dividend in 2019 stopped doing so in 2020. There is also a marked increase in companies diminishing their dividend payments. Around 
$10.60 \%$ of companies reduced their payouts, and $7.66 \%$ cut it by more than $25 \%$. Overall, these statistics confirm that opportunities to trade on ex-dividend dates have strongly decreased with the arrival of the pandemic.

Table 2 exhibits the sample composition by market for companies paying out dividends. Our sample appears representative of the overall European environment with the United Kingdom, France, and Germany being the most represented markets in terms of companies and the number of dividend payouts. A higher payment-frequency in the United Kingdom (bi-annual and quarterly) explains its higher number of payouts.

Table 2

Sample composition of dividend-paying firms

\begin{tabular}{lcccc}
\hline \multirow{2}{*}{ Market } & Firms & & Number of payments & \\
\cline { 4 - 5 } Austria & 45 & 97 & 81 & 16 \\
Belgium & 76 & 209 & 164 & 45 \\
Denmark & 66 & 171 & 144 & 27 \\
Finland & 93 & 273 & 206 & 67 \\
France & 298 & 750 & 611 & 139 \\
Germany & 270 & 637 & 506 & 131 \\
Greece & 35 & 96 & 70 & 26 \\
Ireland & 19 & 70 & 63 & 7 \\
Italy & 149 & 360 & 290 & 70 \\
Netherlands & 63 & 227 & 199 & 28 \\
Norway & 100 & 310 & 247 & 63 \\
Portugal & 19 & 47 & 38 & 9 \\
Spain & 99 & 317 & 268 & 49 \\
Sweden & 223 & 606 & 521 & 85 \\
Switzerland & 192 & 496 & 361 & 135 \\
United Kingdom & 501 & 2,199 & 2,030 & 169 \\
\hline Total & 2,248 & 6,865 & 5,799 & 1,066 \\
\hline Thistable reports & & Tolal & \\
\hline
\end{tabular}

This table reports the number of dividend-paying companies per market and the number of payments done in total, in the pre-COVID period (01/01/2018-23/02/2020), and after the COVID outbreak (24/02/2020-31/07/2020) in Europe.

\section{Empirical results}

Table 3 exhibits AAR over a $[-5 ;+5]$ day window around the ex-dividend date for both the COVID and pre-COVID period as well as CAAR for different windows before and after the ex-dividend date. In both cases, the returns are significantly positive until the ex-dividend date and negative thereafter as investors build up price pressure to capture dividends followed by a 
reversal. Column 3 reports the difference in abnormal returns between the two periods. We observe that the stock price reactions amplified. Investors appear to have traded up the few stocks paying dividends more intensely than in regular times to capture dividends where possible. Arbitrageurs do not appear to have been able to counterbalance this spike in demand with their trades. ${ }^{5}$

Table 3 AAR and CAAR around ex-dividend dates

\begin{tabular}{|c|c|c|c|}
\hline Panel A: AAR & $\begin{array}{c}\text { COVID } \\
\text { (1) }\end{array}$ & $\begin{array}{c}\text { Pre-COVID } \\
(2)\end{array}$ & $\begin{array}{c}\text { Difference } \\
(1)-(2)\end{array}$ \\
\hline-5 & $0.0025 * * *$ & $0.0007 * * *$ & $0.0018 *$ \\
\hline-4 & 0.0006 & $0.0006^{* *}$ & -0.0000 \\
\hline-3 & $0.0015^{*}$ & $0.0006 * *$ & 0.0010 \\
\hline-2 & $0.0036 * * *$ & $0.0011 * * *$ & $0.0024 * * *$ \\
\hline-1 & $0.0046 * * *$ & $0.0010 * * *$ & $0.0036 * * *$ \\
\hline 0 & $0.0087 * * *$ & $0.0069 * * *$ & $0.0018 * *$ \\
\hline+1 & $-0.0058 * * *$ & $-0.0019 * * *$ & $-0.0038 * * *$ \\
\hline+2 & $-0.0032 * * *$ & $-0.0006 * * *$ & $-0.0026 * * *$ \\
\hline+3 & $-0.0026 * * *$ & $0.0004^{*}$ & $-0.0030 * * *$ \\
\hline+4 & $-0.0024 * * *$ & -0.0000 & $-0.0024 * * *$ \\
\hline+5 & -0.0009 & $0.0005 * *$ & $-0.0014^{*}$ \\
\hline Observations & 1,066 & 5,799 & \\
\hline Panel B: CAAR & $\begin{array}{c}\text { COVID } \\
(1)\end{array}$ & $\begin{array}{c}\text { Pre-COVID } \\
\text { (2) }\end{array}$ & $\begin{array}{c}\text { Difference } \\
\text { (1)-(2) }\end{array}$ \\
\hline$[-5 ; 0]$ & $0.0214 * * *$ & $0.0109 * * *$ & $0.0105^{* * *}$ \\
\hline$[-4 ; 0]$ & $0.0189 * * *$ & $0.0102 * * *$ & $0.0087 * * *$ \\
\hline$[-3 ; 0]$ & $0.0184 * * *$ & $0.0096 * * *$ & $0.0087 * * *$ \\
\hline$[-2 ; 0]$ & $0.0168 * * *$ & $0.0091 * * *$ & $0.0078 * * *$ \\
\hline$[-1 ; 0]$ & $0.0133 * * *$ & $0.0079 * * *$ & $0.0053 * * *$ \\
\hline$[+1 ;+2]$ & $-0.0089 * * *$ & $-0.0025 * * *$ & $-0.0064 * * *$ \\
\hline$[+1 ;+3]$ & $-0.0115 * * *$ & $-0.0022 * * *$ & $-0.0094 * * *$ \\
\hline$[+1 ;+4]$ & $-0.0140 * * *$ & $-0.0022 * * *$ & $-0.0118 * * *$ \\
\hline$[+1 ;+5]$ & $-0.0149 * * *$ & $-0.0016 * * *$ & $-0.0132 * * *$ \\
\hline
\end{tabular}

This table reports AAR (Panel A) and CAAR (Panel B) for different time windows around ex-dividend dates for the COVID and pre-COVID period. $* * *, * *, *$ denote significance at the $1 \%, 5 \%$ and $10 \%$-level.

Companies paying higher dividends should be in higher demand by investors wanting to capture dividends. As the pandemic triggered a drop of firms paying dividends, we argue that

\footnotetext{
${ }^{5}$ We run several robustness tests and find that (i) restricting the dataset to companies with a minimum market capitalization of EUR 100 million, (ii) using a pre-COVID period over 2015-2019 or for 2019 only, or (iii) taking the closing price of the ex-dividend day $t_{0}$, all lead to qualitatively very similar results.
} 
this effect was further exacerbated during this period. In Table 4, we observe stronger return patterns for high-dividend stocks than for low-dividend stocks in both the pre-COVID and COVID periods. Moreover, the last column indicates that during the COVID pandemic, highdividend stocks had the largest abnormal returns (in absolute terms). This provides evidence that investors were especially seeking those stocks allowing them to capture the highest possible dividend. These results are confirmed in Figure 1. It illustrates the evolution of the CAAR over a $[-5 ; 5]$ day window for the baseline specification and the one splitting by the intensity of dividend-payment.

\section{Figure 1}

\section{Cumulative average abnormal returns (CAAR)}

Panel A: All firms

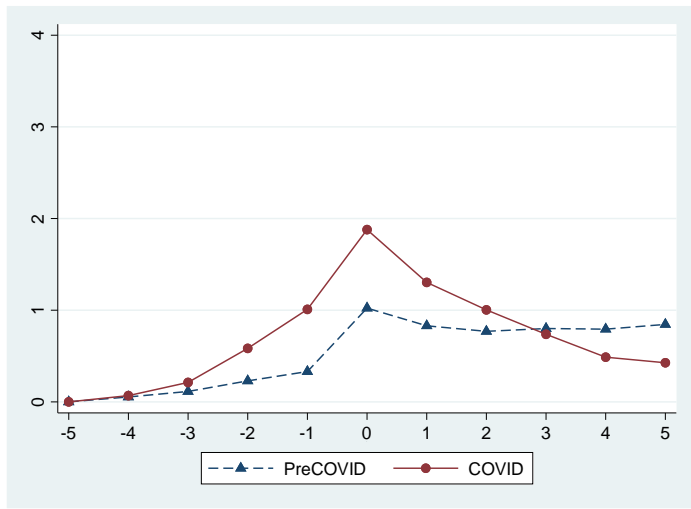

Panel B: High-dividend (left) vs low-dividend (right) firms
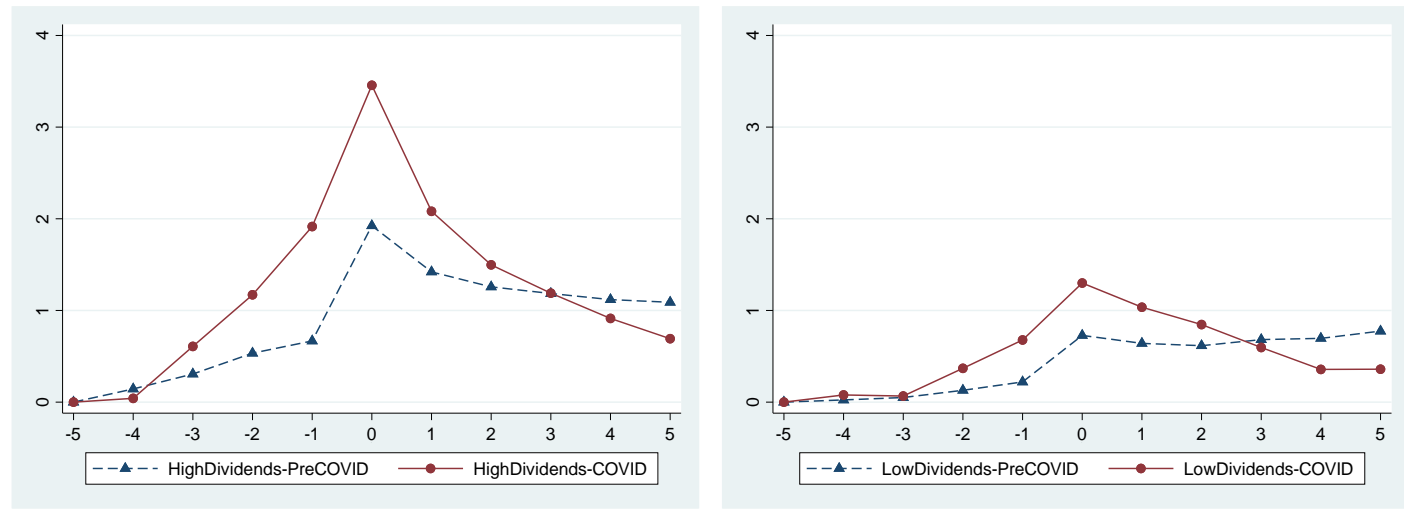

Panel A illustrates the evolution of CAAR, expressed in percent, over a $[-5 ;+5]$ window around the exdividend day. The dashed line denotes the pre-COVID period and the solid line the COVID period. Panel $\mathrm{B}$ illustrates the evolution of CAAR over a $[-5 ;+5]$ window around the ex-dividend day. The left figure contrasts high-dividend stocks (top quartile of annual dividend yield) and the right figure low-dividend stocks (bottom three quartiles of annual dividend yield) over the pre-COVID period (dashed line) and the COVID period (solid line). 
Table 4

AAR and CAAR around ex-dividend dates - high- versus low-dividends

\begin{tabular}{|c|c|c|c|c|c|c|c|}
\hline \multirow[b]{2}{*}{ Panel A: AAR } & \multicolumn{3}{|c|}{ COVID } & \multicolumn{3}{|c|}{ Pre-COVID } & \multirow{2}{*}{$\begin{array}{c}\text { COVID / Pre-COVID } \\
\text { Difference } \\
(1)-(3)\end{array}$} \\
\hline & $\begin{array}{l}\text { High-dividend } \\
\text { (1) }\end{array}$ & $\begin{array}{c}\text { Low-dividend } \\
\text { (2) }\end{array}$ & $\begin{array}{l}\text { Difference } \\
(1)-(2)\end{array}$ & $\begin{array}{c}\text { High-dividend } \\
\text { (3) }\end{array}$ & $\begin{array}{c}\text { Low-dividend } \\
\text { (4) }\end{array}$ & $\begin{array}{c}\text { Difference } \\
(3)-(4)\end{array}$ & \\
\hline-5 & $0.0050 * * *$ & 0.0015 & $0.0035^{*}$ & 0.0006 & $0.0007 * *$ & -0.0001 & $0.0044 * *$ \\
\hline-4 & -0.0001 & 0.0008 & -0.0008 & $0.0010^{* *}$ & $0.0005^{*}$ & 0.0006 & -0.0011 \\
\hline-3 & $0.0034 *$ & 0.0009 & 0.0026 & $0.0013 * * *$ & 0.0003 & $0.0010^{*}$ & 0.0021 \\
\hline-2 & $0.0050 * * *$ & $0.0030 * * *$ & 0.0019 & $0.0016^{* * *}$ & $0.0010 * * *$ & 0.0006 & $0.0033^{*}$ \\
\hline-1 & $0.0055 * * *$ & $0.0042 * * *$ & 0.0013 & $0.0008^{*}$ & $0.0010 * * *$ & -0.0002 & $0.0047 * * *$ \\
\hline 0 & $0.0154 * * *$ & $0.0062 * * *$ & $0.0092 * * *$ & $0.0126^{* * *}$ & $0.0051 * * *$ & $0.0075^{* * *}$ & $0.0028 * *$ \\
\hline+1 & $-0.0139 * * *$ & $-0.0027 * *$ & $-0.0111 * * *$ & $-0.0053 * * *$ & $-0.0008 * *$ & $-0.0045^{* * *}$ & $-0.0086^{* * *}$ \\
\hline+2 & -0.0060 **** & $-0.0021 * *$ & $-0.0039 * *$ & $-0.0014 * * *$ & -0.0004 & $-0.0010^{*}$ & $-0.0046^{* *}$ \\
\hline+3 & $-0.0034 * *$ & $-0.0024 * *$ & -0.0010 & -0.0006 & $0.0007 * * *$ & $-0.0013 * *$ & $-0.0028^{*}$ \\
\hline+4 & $-0.0032 * *$ & $-0.0022 * *$ & -0.0010 & $-0.0009 * *$ & 0.0003 & $-0.0012 * *$ & -0.0022 \\
\hline+5 & -0.0016 & -0.0006 & -0.0010 & -0.0004 & $0.0009 * * *$ & $-0.0013 * *$ & -0.0011 \\
\hline Observations & 288 & 778 & & 1,429 & 4,370 & & \\
\hline & & COVID & & & Pre-COVID & & COVID / Pre-COVID \\
\hline Panel B: CAAR & $\begin{array}{l}\text { High-dividend } \\
\text { (1) }\end{array}$ & $\begin{array}{l}\text { Low-dividend } \\
\text { (2) }\end{array}$ & $\begin{array}{l}\text { Difference } \\
\text { (1)-(2) }\end{array}$ & $\begin{array}{l}\text { High-dividend } \\
\text { (3) }\end{array}$ & $\begin{array}{c}\text { Low-dividend } \\
\text { (4) }\end{array}$ & $\begin{array}{l}\text { Difference } \\
\text { (3)-(4) }\end{array}$ & $\begin{array}{c}\text { Difference } \\
(1)-(3)\end{array}$ \\
\hline$[-5 ; 0]$ & $0.0343 * * *$ & $0.0166^{* * *}$ & $0.0177 * * *$ & $0.0180 * * *$ & $0.0086^{* * *}$ & $0.0094 * * *$ & $0.0163 * * *$ \\
\hline$[-4 ; 0]$ & $0.0292 * * *$ & $0.0151 * * *$ & $0.0141 * * *$ & $0.0173 * * *$ & $0.0079 * * *$ & $0.0095 * * *$ & $0.0119 * * *$ \\
\hline$[-3 ; 0]$ & $0.0293 * * *$ & $0.0143 * * *$ & $0.0150^{* * *}$ & $0.0163 * * *$ & $0.0074 * * *$ & $0.0089 * * *$ & $0.0130 * * *$ \\
\hline$[-2 ; 0]$ & $0.0259 * * *$ & $0.0135 * * *$ & $0.0124 * * *$ & $0.0150 * * *$ & $0.0071 * * *$ & $0.0079 * * *$ & $0.0108 * * *$ \\
\hline$[-1 ; 0]$ & $0.0209 * * *$ & $0.0104 * * *$ & $0.0105^{* * *}$ & $0.0134 * * *$ & $0.0061 * * *$ & $0.0073 * * *$ & $0.0075 * * *$ \\
\hline$[+1 ;+2]$ & $-0.0199 * * *$ & $-0.0049 * * *$ & $-0.0150 * * *$ & $-0.0067 * * *$ & $-0.0012 * * *$ & $-0.0055 * * *$ & $-0.0132 * * *$ \\
\hline$[+1 ;+3]$ & $-0.0232 * * *$ & $-0.0072 * * *$ & $-0.0160 * * *$ & $-0.0073 * * *$ & -0.0005 & $-0.0068 * * *$ & $-0.0160 * * *$ \\
\hline$[+1 ;+4]$ & $-0.0264 * * *$ & $-0.0094 * * *$ & $-0.0170 * * *$ & $-0.0082 * * *$ & -0.0002 & $-0.0080 * * *$ & $-0.0182 * * *$ \\
\hline$[+1 ;+5]$ & $-0.0280 * * *$ & $-0.0100 * * *$ & $-0.0180 * * *$ & $-0.0086 * * *$ & 0.0007 & $-0.0092 * * *$ & $-0.0194 * * *$ \\
\hline Observations & 288 & 778 & & 1,429 & 4,370 & & \\
\hline
\end{tabular}

This table reports AAR (Panel A) and CAAR (Panel B) for different time windows around ex-dividend dates for the COVID and pre-COVID period. The sample is further split into High-dividend for companies in the yearly upper quartile of dividend yields and Low-dividend for other firms. $* * *, * * *$ denote significance at the $1 \%, 5 \%$ and $10 \%$-level. 
Table 5 further confirms our main findings in a multivariate setting controlling for firmcharacteristics such as risk, firm size, industry- and country-effects. Consistent with existing literature and our previous results, regression analyses confirm stronger return patterns for firms paying high dividends regardless of the window considered. Relative to the pre-COVID period, results display a higher cumulated abnormal return preceding the ex-dividend day during the COVID period. We further observe the inverse effect following ex-dividend days. ${ }^{1}$ This result remains valid for both low- and high-dividend payers and supports the hypothesis of an increase in price pressure due to a shortage of dividends during the pandemic. The strong positive abnormal returns of high-dividend stocks lead to a significantly stronger reversal effect and more negative abnormal returns when investors unwind their positions.

Table 5

Regression analysis on AAR and CAR

\begin{tabular}{|c|c|c|c|c|c|}
\hline & $\begin{array}{c}(1) \\
\text { CAR(-5;0) }\end{array}$ & $\begin{array}{c}(2) \\
\text { CAR(-1;0) }\end{array}$ & $\begin{array}{c}(3) \\
\operatorname{AAR}(0) \\
\end{array}$ & $\begin{array}{c}(4) \\
\operatorname{AAR}(+1) \\
\end{array}$ & $\begin{array}{c}(5) \\
\text { CAR }(+1 ;+5) \\
\end{array}$ \\
\hline High_COVID & $\begin{array}{c}0.024 * * * \\
(0.004)\end{array}$ & $\begin{array}{c}0.013 * * * \\
(0.002)\end{array}$ & $\begin{array}{c}0.008 * * * \\
(0.001)\end{array}$ & $\begin{array}{c}-0.013 * * * \\
(0.002)\end{array}$ & $\begin{array}{c}-0.027 * * * \\
(0.004)\end{array}$ \\
\hline Low_COVID & $\begin{array}{c}0.008 * * * \\
(0.002)\end{array}$ & $\begin{array}{c}0.004 * * * \\
(0.001)\end{array}$ & $\begin{array}{c}0.001 \\
(0.001)\end{array}$ & $\begin{array}{l}-0.002 \\
(0.001)\end{array}$ & $\begin{array}{c}-0.011 * * * \\
(0.002)\end{array}$ \\
\hline High_preCOVID & $\begin{array}{c}0.008 * * * \\
(0.001)\end{array}$ & $\begin{array}{c}0.006 * * * \\
(0.001)\end{array}$ & $\begin{array}{c}0.006 * * * \\
(0.001)\end{array}$ & $\begin{array}{c}-0.004 * * * \\
(0.001)\end{array}$ & $\begin{array}{c}-0.008 * * * \\
(0.001)\end{array}$ \\
\hline Relative risk & $\begin{array}{c}0.000 \\
(0.000)\end{array}$ & $\begin{array}{l}-0.000 \\
(0.000)\end{array}$ & $\begin{array}{c}0.000 \\
(0.000)\end{array}$ & $\begin{array}{l}-0.000 \\
(0.000)\end{array}$ & $\begin{array}{c}-0.000 * * \\
(0.000)\end{array}$ \\
\hline Size & $\begin{array}{c}-0.002 * * * \\
(0.000)\end{array}$ & $\begin{array}{c}-0.002 * * * \\
(0.000)\end{array}$ & $\begin{array}{c}-0.001 * * * \\
(0.000)\end{array}$ & $\begin{array}{l}0.000 * \\
(0.000)\end{array}$ & $\begin{array}{c}0.002 * * * \\
(0.000)\end{array}$ \\
\hline Beta & $\begin{array}{c}-0.005 * * \\
(0.002)\end{array}$ & $\begin{array}{l}-0.002 * \\
(0.001)\end{array}$ & $\begin{array}{l}-0.001 \\
(0.001)\end{array}$ & $\begin{array}{c}0.000 \\
(0.001)\end{array}$ & $\begin{array}{c}-0.004 * * \\
(0.002)\end{array}$ \\
\hline Constant & $\begin{array}{c}0.030 * * * \\
(0.004)\end{array}$ & $\begin{array}{c}0.019 * * * \\
(0.002)\end{array}$ & $\begin{array}{c}0.013 * * * \\
(0.001)\end{array}$ & $\begin{array}{l}-0.002 \\
(0.002)\end{array}$ & $\begin{array}{l}-0.006 \\
(0.004)\end{array}$ \\
\hline Industry FE & YES & YES & YES & YES & YES \\
\hline Country FE & YES & YES & YES & YES & YES \\
\hline Observations & 6,857 & 6,857 & 6,857 & 6,857 & 6,857 \\
\hline R-squared & 0.048 & 0.068 & 0.109 & 0.021 & 0.041 \\
\hline $\begin{array}{l}\text { This table reports C } \\
\text { period. High_COVIl } \\
\text { bottom three quartile } \\
\text { yield companies in } \\
\text { benchmark index, an } \\
\text { logarithm of the mar } \\
\text { are clustered at the f }\end{array}$ & $\begin{array}{l}\text { AAR for } \\
\text { s yearly u } \\
\text { d yield co } \\
\text { COVID p } \\
\text { he coeffici } \\
\text { alization o } \\
l . * * * * *\end{array}$ & $\begin{array}{l}\text { it time win } \\
\text { lartile divid } \\
\mathrm{s} \text { in the CO } \\
\text { Relative ris } \\
\text { stock's ret } \\
\text { pany. All re } \\
\text { te significal }\end{array}$ & $\begin{array}{l}\text { Und ex-di } \\
\text { d compani } \\
\text { iod, and } H \\
\text { ned as the } \\
\text { ressed on } \\
\text { s include }\end{array}$ & $\begin{array}{l}\text { dates for } \\
\text { ee COVID } \\
\text { eCOVID y } \\
\text { ce of a s } \\
\text { hmark inc } \\
\text { and indus } \\
\text { h-level }\end{array}$ & $\begin{array}{l}\text { ID and pre-COVID } \\
\text { Low_COVID yearly } \\
\text { per quartile dividend } \\
\mathrm{r} \text { the variance of its } \\
\text { ns. Size is the natural } \\
\text { mies. Standard errors }\end{array}$ \\
\hline
\end{tabular}

${ }^{1}$ Splitting dividend-paying stocks at the yearly median instead of the top-quartile yields qualitatively similar results for Tables 4 and 5. 


\section{Conclusions}

It is well-documented that price pressure by investors seeking dividends leads to positive abnormal returns before ex-dividend days and a subsequent reversal. The COVID-19 pandemic has induced a severe drop in both the number of dividend-paying firms and the amounts distributed. It thus provides a unique setting to examine the impact on prices by dividend-seeking investors around ex-dividend days. Compared to previous years, we observe a doubling in the magnitude of stock return patterns around this date. This indicates that dividend capture plays an important role in price formation around the ex-date and that arbitrageurs have not sufficiently offset the spike in interest for companies still paying dividends.

\section{References}

Ainsworth, A., and Nicholson, M., 2014. Can Dividend Schedules Predict Abnormal Returns? International Evidence. Working Paper.

Allen, F., and Michaely, R., 2003. Payout Policy. In: Constantinides, G. M., Harris, M., and Stulz, R. M., (Eds.), Handbook of the Economics of Finance. Elsevier, Amsterdam, pp. 337-429.

Baker, M., and Wurgler, J., 2004. A Catering Theory of Dividends. Journal of Finance 59, 11251165.

Bali, R., and Hite, G. L., 1998. Ex Dividend Day Stock Price Behavior: Discreteness or TaxInduced Clienteles? Journal of Financial Economics 47, 127-159.

Berkman, H., and Koch, P. D., 2017. Drips and the Dividend Pay Date Effect. Journal of Financial and Quantitative Analysis 52, 1765-1795.

Bessembinder, H., and Zhang, F., 2015. Predictable Corporate Distributions and Stock Returns. Review of Financial Studies 28, 1199-1241.

Brown, S. J., and Warner, J. B., 1985. Using Daily Stock Returns: The Case of Event Studies. Journal of Financial Economics 14, 3-31.

Campbell, J., Lo, A., and MacKinlay, C., 1997. The Econometrics of Financial Markets. Princeton University Press, Princeton.

Campbell, J. A., and Beranek, W., 1955. Stock Price Behavior on Ex-Dividend Dates. Journal of Finance 10, 425-429. 
Eades, K. M., Hess, P. J., and Kim, E. H., 1985. Market Rationality and Dividend Announcements. Journal of Financial Economics 14, 581-604.

Eades, K. M., Hess, P. J., and Kim, E. H., 1994. Time-Series Variation in Dividend Pricing. Journal of Finance 49, 1617-1638.

Elton, E., and Gruber, M., 1970. Marginal Stockholder Tax Rates Andthe Clientele Effect. Review of Economics and Statistics 52, 68-74.

Farre-Mensa, J., Michaely, R., and Schmalz, M., 2014. Payout Policy. Annual Review of Financial Economics 6, 75-134.

Frank, M., and Jagannathan, R., 1998. Why Do Stock Prices Drop by Less Than the Value of the Dividend? Evidence from a Country without Taxes. Journal of Financial Economics 47, 161-188.

Harris, L. E., Hartzmark, S. M., and Solomon, D. H., 2015. Juicing the Dividend Yield: Mutual Funds and the Demand for Dividends. Journal of Financial Economics 116, 433-451.

Hartzmark, S. M., and Solomon, D. H., 2013. The Dividend Month Premium. Journal of Financial Economics 109, 640-660.

Hartzmark, S. M., and Solomon, D. H., 2018. Recurring Firm Events and Predictable Returns: The within-Firm Time Series. Annual Review of Financial Economics 10, 499-517.

Hartzmark, S. M., and Solomon, D. H., 2019. The Dividend Disconnect. Journal of Finance 74, 2153-2199.

Kalay, A., 1982. The Ex-Dividend Day Behavior of Stock Prices: A Re-Examination of the Clientele Effect. Journal of Finance 37, 1059-1070.

Koo, B., and Chae, J., 2020. Dividend Month Premium in the Korean Stock Market. Journal of Derivatives and Quantitative Studies.

Kreidl, F., and Scholz, H., 2020. Exploiting the Dividend Month Premium: Evidence from Germany. Working Paper.

Lakonishok, J., and Vermaelen, T., 1986. Tax-Induced Trading around Ex-Dividend Days. Journal of Financial Economics 16, 287-319.

Michaely, R., and Vila, J.-L., 1995. Investors' Heterogeneity, Prices, and Volume around the ExDividend Day. Journal of Financial and Quantitative Analysis 30, 171-198.

Zhang, Y., Farrell, K. A., and Brown, T. A., 2008. Ex-Dividend Day Price and Volume: The Case of 2003 Dividend Tax Cut. National Tax Journal 61, 105-127. 


\author{
Authors \\ Nicolas EUGSTER \\ University of Queensland, University of Queensland Business School, St Lucia, Brisbane 4072, Australia. \\ Email: n.eugster@uq.edu.au. More information on https://nicolaseugster.com/ \\ Romain DUCRET \\ University of Fribourg, Boulevard de Pérolles 90, CH-1700 Fribourg, Switzerland, \\ email: romain.ducret@unifr.ch. More information on https://www.unifr.ch/cgf \\ Dušan ISAKOV \\ University of Fribourg, Boulevard de Pérolles 90, CH-1700 Fribourg, Switzerland, \\ email: dusan.isakov@unifr.ch. More information on https://www.uniff.ch/cgf
}

\title{
Jean-Philippe WEISSKOPF
}

Ecole hôtelière de Lausanne, HES-SO Haute école spécialisée de Suisse Occidentale, Route de Cojonnex 18, 1000 Lausanne, Switzerland. Email: jean-philippe.weisskopf@ehl.ch. More information on https://weisskopf.weebly.com/

\begin{abstract}
This paper investigates the impact of the COVID-19 pandemic on the trading behavior of investors around ex-dividend dates in Europe. The sudden decrease in the number of companies paying dividends reduced the opportunities to capture dividends. The firms that have maintained dividend payments during the pandemic thus attracted more interest than before. This led to a doubling in the magnitude of stock return patterns usually observed around exdividend days. Our evidence indicates that dividend-seeking investors are likely to be the main driver of the price patterns observed around ex-dividend dates.
\end{abstract}

\section{Citation proposal}

Nicolas Eugster, Romain Ducret, Dušan Isakov, Jean-Philippe Weisskopf. 2020. «Chasing dividends during the COVID-19 pandemic». Working Papers SES 520, Faculty of Economics and Social Sciences, University of Fribourg (Switzerland)

\section{Jel Classification}

G12; G14; G35.

\section{Keywords}

COVID-19; dividend capture; price pressure; ex-dividend date; event study.

\section{Working Papers SES collection}

\section{Last published}

513 Wallimann H., Imhof D., Huber M.: A Machine Learning Approach for Flagging Incomplete Bid-rigging Cartels; 2020

514 Huber M., Lafférs L.: Bounds on direct and indirect effects under treatment/mediator endogeneity and outcome attrition; 2020

515 Farbmacher H., Huber M., Langen H., Spindler M.: Causal mediation analysis with double machine learning; 2020

516 Fernandes A., Huber M., Vaccaro G.: Gender Differences in Wage Expectations; 2020

517 Deschênes S., Dumas C., Lambert S.: Household Resources and Individual Strategies; 2020

518 Dumas C., Jàativa X.: Better roads, better off? Evidence on improving roads in Tanzania; 2020

519 Huber M., Imhof D., Ishii R.: Transnational machine learning with screens for flagging bid-rigging cartels; 2020

\section{Catalogue and download links}

http://www.unifr.ch/ses/wp

http://doc.rero.ch/collection/WORKING_PAPERS_SES

\section{Publisher}

Université de Fribourg, Suisse, Faculté des sciences économiques et sociales et du management Universität Freiburg, Schweiz, Wirtschafts- und sozialwissenschaftliche Fakultät University of Fribourg, Switzerland, Faculty of Management, Economics and Social Sciences

Bd de Pérolles 90 $\mathrm{CH}-1700$ Fribourg Tél.: +41(0) 263008200 decanat-ses@unifr.ch www.unifr.ch/ses 